УДК 94(477.83)»195»:730.071.1

DOI: https://doi.org/10.31470/2518-7600-2021-13-229-256

THE ARTIST VS. AUTHORITARIAN POWER: THE ARTISTIC ENVIRONMENT OF SOVIET LVIV IN THE SECOND HALF OF THE XX CENTURY

\title{
МИТЕЦЬ VS АВТОРИТАРНА ВЛАДА: ТВОРЧЕ СЕРЕДОВИЩЕ РАДЯНСЬКОГО ЛЬВОВА ДРУГОЇ ПОЛОВИНИ ХХ СТОЛІТТЯ
}

\section{ХУДОЖНИК VS АВТОРИТАРНАЯ ВЛАСТЬ: ТВОРЧЕСКАЯ СРЕДА СОВЕТСКОГО ЛЬВОВА ВТОРОЙ ПОЛОВИНЫ ХХ ВЕКА}

\section{Любомир Хахула,}

кандидат історичних наук,

старший науковий

співробітник Центру

дослідження українсько-

польських відносин;

провідний науковий

співробітник

1.khakhula@gmail.com

https:/orcid.org/0000-0002-

9954-9962

ID: B-9306-2019

Інститут українознавства імені

I. Крип'якевича НАН України, вул. Козельницька, 4, м. Львів, 79026; Комунального закладу Львівської обласної ради «Львівський історичний музей», пл. Ринок, 6, м. Львів, 79008

\section{Liubomyr Khakhula,}

Ph.D. in Historical sciences, Senior Researcher of Center for the Study of Ukrainian-Polish Relations; Leading Researcher, 1.khakhula@gmail.com https://orcid.org/0000-00029954-9962

ID: B-9306-2019

Ivan Krypiakevych Institute of Ukrainian Studies, National Academy of Sciences of Ukraine, 4 Kozelnytska Str., Lviv, 79026; Municipal Institution of the Lviv Regional Council «Lviv Historical Museum», 6 Rynok Sq., Lviv, 79008 


\section{Василь Ільницький,}

доктор історичних наук, професор, завідувач кафедри історії України; доцент кафедри мобілізаційної, організаційно-штатної, кадрової роботи та оборонного планування

vilnickiy@gmail.com

http://orcid.org/0000-00024969-052X

ID: H-4431-2017

Scopus ID: 57203399830

Дрогобицький державний педагогічний університет імені Івана Франка, вул. Івана Франка, 24, м. Дрогобич, 82100; Національна академія сухопутних військ імені гетьмана Петра Сагайдачного, вул. Героїв Майдану, 32,

м. Львів, 79026

\section{Vasyl Ilnytskyi,}

Ph.D. hab. in Historical

sciences, Professor, Head of the

Department of Ukraine's

History; Associate Professor of the Department of Mobilization, Organizational, Staffing, Human Resources and Defense Planning vilnickiy@gmail.com http://orcid.org/0000-00024969-052X

ID: H-4431-2017

Scopus ID: 57203399830

Ivan Franko Drohobych State

Pedagogical University, 24, Ivan Franko Str., Drohobych, 82100; National Academy of Land Forces named after Petro Sahaidachnyi, 32, Heroyiv Maydana Str., Lviv, 79026

\section{ABSTRACT}

The purpose of the work is in integrated analysis the sociopolitical and creative strategies of Lviv sculptors - master of Ukrainian medal art Liubomyr Terletskyi and author of monumental and easel sculpture Valentyn Borysenko - in the second half of the XX century. The methodological basis of the work was developed in the fields of political history, cultural anthropology, social history, art history. The proposed study is based on the methodological principle of "case study», which allowed to apply the system and structural method for reveal the multidimensional history of commonness - creative and career paths of Lviv sculptors of the Soviet period. The scientific novelty of the study lies in the successful application of a microhistorical approach to demonstrate 
the then opposition models of «creativity-dictatorship» and «artistauthoritarian power», as well as ways of expressing them in the conditions of Soviet political and ideological control. It is proved that Lviv sculptors L. Terletskyi and V. Borysenko had different experiences of professional and creative growth, and thus expressed different political and cultural horizons. As a result of the study, conclusions were drawn. The artistic environment of postwar Lviv was formed through the active subordination of artistic creativity to the goals of the Soviet state and party apparatus. The adoption of the style of socialist realism required from artists to adapt to primitive forms of expression of ideological postulates of the Soviet Union. Remaining the dominant direction of art, socialist realism forced Lviv sculptors to build individual strategies of creativity, professional growth, and relations with the authorities. Liubomyr Terletskyi (1922-1993), being repressed for his active patriotic position at young age, sustained the terror of the Soviet camps and, after rehabilitation, returned to creative life. Having no illusions about the prospects of the authoritarian Soviet regime, he learned and popularized the millennial history of Ukraine. Not only by sculptural work, but also by scientific work, the artist demonstrated the adamantine character and conviction of the inevitability of state, political and cultural revival of the Ukrainians. The author of monumental and easel sculptures Valentyn Borysenko (1929-1990) went down in history as a typical representative of the Soviet school of sculpture, a master who fit well into the dogma of socialist art imposed by the party. At the same time, being formed in the Lviv artistic tradition ( $V$. Borysenko's teachers were representatives of Cracow, Prague, Roman artistic schools), he, due to the appeal to the princely era or folk vengeful characters of the XVIII century, partially dissociated himself from Soviet ideological layers. Having chosen a party and administrative career, V. Borysenko repeatedly carried out outspoken propaganda work commissioned by partypolitical structures.

Keywords: Lviv, Soviet Union / Ukrainian SSR, sculpture, socialist realism, Liubomyr Terletskyi, Valentyn Borysenko, party and ideological control. 
Постановка проблеми. Наукове осмислення тоталітарного / авторитарного минулого неможливе без комплексного дослідження культурно-мистецьких процесів. Новітній український досвід декомунізації публічних просторів актуалізував питання взаємовідносин митців та влади в період СРСР. Радянські форми ідеологічно-партійного контролю над духовним та культурним світом громадян особливо були відчутними в такому виді образотворчого мистецтва як скульптура. Директивне впровадження в мистецтво стилю соціалістичного реалізму відображало прагнення влади до перетворення дійсності, штучного конструювання «комуністичного світогляду». Інструментами такого впливу ставали монументальні та станкові форми скульптурного мистецтва, покликані утверджувати радянську ідеологічну парадигму. Особливого характеру цей процес набув у західних областях УРСР після 1945 р., зокрема у Львові, де нова радянська культурна політика зіштовхнулася із європейською мистецькою традицією. Тому для сучасної української історичної науки актуальним викликом залишається дослідження участі митців-скульпторів у (не)підтримці радянського ладу через творчість, громадсько-адміністративну діяльність, участь у соціокультурних процесах середини другої половини XX ст.

Аналіз історіографії питання. Практика політичного та ідеологічного диктату в царині мистецтва та мистецтвознавства залишається актуальною проблемою для української історіографії. В останні десятиліття з'явилися праці, присвячені ідеологічним аспектам авторитарного контролю над мистецтвом в СРСР. Так, львівський науковець Маркіян Нестайко вивчив механізми відносин влади та мистецтвознавців Львова у третій чверті XX ст. (Нестайко, 2017). Соцреалістичний вимір мистецького середовища Львова другої половини ХХ ст. розкрив Орест Голубець (Голубець, 2001). Культурномистецьку ситуацію у Львові, відносини митця $з$ владою та насильницьке впровадження у мистецтво 
засад соціалістичного реалізму проаналізувала Мар'яна Мусій (Мусій, 2009: 71-74). Львівську скульптурну школу досліджували Богдан Горинь (Горинь, 1996), Володимир Грабовецький (Грабовецький, 2009), Лідія Коць-Григорчук (Коць-Григорчук, 1998: 333-338), Микола Моздир (Моздир, 1971; Моздир, 1987), Анатоль Яненко (Яненко, 2006: 43). Разом 3 тим нерозкритими залишаються аспекти професійного становлення та творчої діяльності львівських скульпторів у контексті повсюдного авторитарного контролю в СРСР.

Мета статті. Метою пропонованої статті $\epsilon$ аналіз суспільно-політичних та творчих практик львівських митців у середині - другій половині XX століття. На прикладі діяльності видатного майстра української медальєрної пластики Любомира Терлецького та знаного творця монументальної і станкової скульптури Валентина Борисенка продемонстровано тогочасні опозиційні моделі «творчість-диктатура» та «митецьавторитарна влада», а також способи їх вираження в умовах радянського політико-ідеологічного контролю.

Результати досліджень. Характеризуючи мистецькотворчі процеси Львова у 1939-1941 рр., український дослідник мистецтва Роман Яців зазначив: «Враховуючи, що до вересня 1939 р. митці Львова здебільшого були зорієнтовані на західноєвропейські художні процеси, а за концепціями мистецтва тяжіли до модерністичних течій, приїжджі функціонери ввели план 3 насильної індоктринації у мистецький простір міста ідей соцреалізму, пролетарської культури i російського передвижництва як «предтечі» соціалістичної культури» (Яців, 2007: 189). Послідовні кроки 3 підпорядкування мистецтва державно-партійному апарату продовжено після 1944 року. Мистецький клімат повоєнного Львова характеризувався впровадженням стилю соціалістичного реалізму, який вимагав від митців пристосування до «примітивного трактування ідеологічних постулатів тоталітарної держави» (Голубець, 2001: 106). Під приводом боротьби 3 формалізмом партійне керівництво 
відбирало у митців право на авторське трактування пластики та використання кольору. Скульптура, як i iнші жанри мистецтва, мала завдання реалізовувати ідеологічні постулати партії. Тому закономірними вважалися масові замовлення на пам'ятники революціонерам, визволителям, вождям партії. Вказані фігури виконували у зазвичай величезних розмірах, що теж було характерним для імперської традиції. Як підкреслив львівський мистецтвознавець Орест Голубець, у «радянському мистецтві розмір твору став мірилом його значимості, а також гонорару доступного для «вибраних» (Голубець, 2001: 106). Разом $з$ тим, аналіз творчих стратегій окремих львівських скульпторів демонструє поліваріативність способів взаємодії із радянським політичним режимом.

\section{Любомир Терлецький: творчість всупереч режиму}

Відомий український мистецтвознавець, громадськополітичний діяч Богдан Горинь, характеризуючи життєвий шлях та творчість Любомира Терлецького зазначив: «Любомир Терлецький залишиться в моїй пам'яті унікальною постаттю української культури, глибоким знавцем історичної проблематики їі ілюстратором, особистістю з неординарним характером та чітко поставленою метою, досягненню якої присвятив все своє життя» (Архів автора).

Народився Любомир-Богдан Терлецький 16 травня 1922 p. у родині вчителів в с. Сков'ятин, Борщівського повіту Тернопільського воєводства Другої Речі Посполитої. 1930 р., після закінчення шестирічної народної школи сестер василіянок, Л. Терлецький разом з батьками переїхав до Львова, де розпочав навчання у Першій академічній гімназії (Коць-Григорчук, 1998: 334).

Слід зазначити, що серед тодішніх учнів Академічної гімназії за лише 10-15\% походили зі Львова. Більшість з них це були селянські, міщанські та священичі діти 3 усієї Галичини. Не всі вони доходили до матури, бо вимоги до навчання були набагато складніші, ніж у нинішніх середніх і 
навіть вищих школах. Однак ті кілька тисяч вихованців Академічної гімназії, які вийшли з їі класів до 1939 року, стали справді елітою Галичини (Мельник, 2005). Випускник та пізніший вчитель гімназії Степан Шах писав: «Побіч грекокатолицької (візантійсько-католицької) церкви дала львівська Академічна гімназія протягом другої половини XIX і першої половини XX ст. західній вітці українського народу його національно-політичне обличчя; a через політичну приналежність до Австрії і завдяки плеканню знання греки і латини впровадила вона галичан в орбіту західноєвропейської культурної спільноти (...) з якої натомість східня Україна, силою географічних, імперсько-політичних i релігійних обставин, як складова частина Росії (...) виелімінувалась і разом із Росією увійшла в євразійську спільноту!» (Шах, 1956: 328).

У 20-30-х рр. ХХ ст. в Академічній гімназії діяли нелегальні юнацькі осередки Української військової організації, Організації українських націоналістів, до яких входили учні старших класів. Значна частина учнів гімназії були членами української молодіжної організації «Пласт» (3 історії гімназії, 2021). Л. Терлецький брав активну участь у діяльності Юнацтва ОУН у гімназії, певний час був його провідником.

3 початком Другої світової війни та інкорпорацією Західної України до СРСР влада розпочала масові репресії проти діячів культури й науки, учнівської та студентської молоді (Литвин \& Ільницький, 2020). У липні 1940 р. заарештували і Любомира Терлецького, звинувативши у підпільній діяльності проти СРСР (розвідка, виховання, конспірація, військова підготовка, вербування нових членів) (ГДА СБУ у Львівській обл., спр. № П 8145, т. 1: 1). У 1941 р. Військовий трибунал Київського військового особливого округу, на підставі сфальсифікованих документів засудив Л. Терлецького до розстрілу. Верховний Суд СРСР замінив кару на 10 років тюрми і 5 - заслання. Перших десять років 
Л. Терлецький відбув у Печорі, важко працюючи на лісокомбінаті та теплоелектростанції, наступних сім - на спецпоселенні у Красноярському краї. Перебуваючи в Сибірі одружився із Іриною Преображенською, донькою відомого економіста Свгена Преображенського, репресованого радянською владою i засудженого до розстрілу (КоцьГригорчук, 1998: 337).

10 березня 1956 р. Л. Терлецький написав прохання на ім’я Микити Хрущова, просив помилування, аргументуючи це тим, що 17 років відбуває покарання за злочин, якого не скоїв, за сфабрикованими звинуваченнями, одержаними під тортурами. 4 серпня 1956 р. Терлецького допитали, як свідка. За сприяння композитора Анатолія Кос-Анатольського та голови Львівської облради Семена Стефаника у 1957 р. Л. Терлецький повернувся до Львова, до матері i батька (Сливка, 2007: 8). Мешкав у Львові з батьками на вул. Леонтовича 8/5, працював електриком. 22 лютого 1957 р. у кримінальній справі записано, що Л. Терлецький вибув до Сталіно (сьогодні - Донецьк) (ГДА СБУ у Львівській обл., спр. № П 8145 , т. 1: 4).

У 1960 р., закінчивши десятирічку, Л. Терлецький вступив на факультет інтер'єру і меблів вечірнього відділення Львівського державного інституту прикладного та декоративного мистецтва, який закінчив у 1964 році (Фіголь, Криса, 2006: 387). Після закінчення навчання зацікавився скульптурою, а сестра Лідія, яка в роки Другої світової війни емігрувала до США, допомогла облаштувати майстерню (КоцьГригорчук, 1998: 337). Своєрідним девізом художника були слова: «Те, що я творю, відображаючи українську історію в своїх роботах, це те саме, що носити кріси на фронті» (Сливка, 2007: 7). У 1972 р. скульптора обрали членом Спілки художників України.

У радянський період свої твори Л. Терлецький виставляв на окремих виставках: обласній виставці у Львові (медаль «Пам'яті В. Стефаника») та Всесоюзній виставці у Москві 
(медаль «Вічна слава полеглим героям») у 1970 р. (КоцьГригорчук, 1998: 336). На черговій московській виставці 1980 р. медаль «Пам'яті десантників» була нагороджена однією 3 основних премій. У 1987 р. в тодішньому Львівському музеї українського мистецтва відбулася перша персональна виставка творів Л. Терлецького, репрезентованих круглою скульптурою монументального і станкового типів, та плакетками і медалями. Рівень значущості робіт митця можна зрозуміти із запису у книзі відгуку авторства Михайла Гориня: «Народ без минулого - народ без майбутнього. Коли справжній митець припадає до джерел, з'являються твори, гідні великого народу. Низький поклін великому скульптору, що розкрив перед нами художню історію нашого народу на такому високому рівні» (Коць-Григорчук, 1998: 335-336).

Крім скульптурної творчості, Л. Терлецький поринув у науково-дослідну роботу, розпочавши писати книгу про витоки українського народу. Розуміючи неможливість їі публікації у тоталітарні часи, він писав книгу у вільній від цензури атмосфері. У книзі автор прагнув з'ясувати час формування українського народу «спочатку, як окремих етнокультурних компонентів, а згодом і сам етногенез упродовж тисячоліть» (Сливка, 2007: 12). Друком книга вийшла лише у 2007 р. (Терлецький, 2007).

У 1983 р. скульптор важко захворів, ним опікувалася Катерина Шинкаренко, помер 25 вересня 1993 р. Похований на Личаківському кладовищі у Львові.

Після смерті митця, частину збережених гіпсових медалей i плакеток, коштом сестри Лідії ТерлецькоїДобровольської відлито в бронзі. Л. Терлецька-Добровольська подарувала їх (47 одиниць) Національному музеєві у Львові із умовою виставляти декілька творів на постійній експозиції, а 3 нагоди ювілейних дат автора виставляти всі його роботи для широкого загалу (Коць-Григорчук, 1998: 335). 6 лютого 1998 р. відбулася перша повна виставка творів Л. Терлецького, 
переданих до Музею.

Будучи учнем відомого скульптора Дмитра Крвавича Л. Терлецький, і сам пробував себе у монументальному мистецтві (твори «Бескид i Чорногора» (знаходиться в Золочівському замку), «Голубка», «Сім'я», був автором надгробного пам'ятника на могилі своїх батьків на Янівському цвинтарі). На думку Лідії Коць-Григорчук, «добре володіючи мистецтвом високого рельєфу i контрельєфу, зумів Л. Терлецький домогтися виразної пластичності образів, причому використовував контррельєф не тільки тоді, коли накреслював контури зображуваного, але й для створювання та поглиблювання тіней» (Коць-Григорчук, 1998: 335).

Зацікавленість митця давньою історією України знайшла вираз й у медальєрній пластиці. У фондовій групі «Скульптура» Львівського історичного музею знаходяться медальйони й плакетки «Поляне Русь», «Десятинна церква в Києві» «Похід новгород-сіверського князя Ігоря Святославича на половців навесні 1185 р.» автором Музеєві у 1979 р. (Архів ЛІМу, Акти надходження музейних предметів, 1980: 175-176).

На медальйоні «Поляне Русь» розкрито етногенезу племінного союзу в державне утворення. На лицевій стороні зображений чоловік, який оре дерев'яним плугом, за ним давньоруський меч. Праворуч видніє собор Софії і написи: «Киев, Чернигов, Переяслав». 3 лівого боку напис: «Поляне» $\mathrm{i}$ кінь $з$ плугом. Внизу «Русь» (Архів ЛІМу, Інвентарна книга експонатів фондової групи «Скульптура», т. 1: 56). Напис $є$ уривком із Літопису «Поляне яже ныне зовомая Русь». На плакетці «Десятинна церква в Києві зображено частину черепа, знайденого під час розкопок місця, де стояла церква. На горішній частині барельєфу мініатюрний собор і напис «Володимер церков святия Богородица конча зижа * 996». Внизу: «1240 Приде Батый Кыеву бысть брань Велика людем избъгшим на церковь И повалишася с ними стъни прият Бисть град воими» (Архів ЛІМу, Інвентарна книга експонатів фондової групи «Скульптура», т. 1: 56-57). Невдалий похід 
1185 року на половців художник розкрив твором, де зобразив воїна на коні, який задивився на затьмарене сонце, що віщує нещастя. Кінь схилив голову, неначе передчуває якусь біду. Вгорі напис старослов'янською мовою: «Солнце тьмою путь застуше». На іншій плакетці зображено жінку, яка символізує трагедію Русі після розгрому походу Ігоря на половців. 3 правого боку напис: «1187 Украина много постона». Останні два твори проілюстрував запис з Повісті временних літ є такий запис: «У РІК 6695 [1187]. Надумав князь Святослав зі сватом своїм Рюриком піти на половців. (...) Володимир Глібович також приїхав до них із Переяславля з дружиною своєю. (...) У тім же поході розболівся Володимир Глібович недугою тяжкою, од якої він і скончався. I принесли його в город його Переяславль на носилицях, і тут преставився він, (...), i покладений був у церкві святого Михайла, і плакали по ньому всі переяславці. (...) За ним же Україна багато потужила» (Махновець, 1989: 342-343).

Як вважав мистецтвознавець Василь Глинчак, цими плакетками скульптор на свій манер відзначив 800-річчя «нашого національного імені. Й не тільки відзначив, але й дав свою відповідь на те, що «много постонати» - «дуже затужити» - могла лише якась конкретна органічна цілість земля, волость, край, сторона, країна, а не якась «окраїна», не якесь аморфне, безлике «пограниччя»! I тому для нього було так природно й очевидно зобразити ту тужливу Україну в образі суворо-скорбної матері» (Глинчак, 2012, 18).

\section{Валентин Борисенко: творчість в координатах режиму}

Сучасний публічний простір міста Львова назначений скульптурами, створеними в період УРСР, зокрема й авторства В. Борисенка. Працюючи в царині монументальної і станкової скульптури митець залишив досить значну спадщину почасти нашаровану ідеологічно. Його монументальні твори (пам'ятники, монументи) пов'язані 3 архітектурним середовищем, вирізнялися високим рівнем узагальнення, 
великими розмірами. Станкові скульптури В. Борисенка виражали конкретні історично-культурні проблеми, підтримували партійні політичні пріоритети.

Народився майбутній скульптор 2 травня 1929 р. в с. Озеряни Бобровицького району Чернігівської області в селянській родині. Втративши рано батька і старшого брата у 1944 р., закінчивши 7 клас, В. Борисенко навчався на відділенні живопису Київського училища прикладного мистецтва, яке закінчив у 1947 році (Архів ЛНАМ, Особова справа № 3185 : 19). Тоді ж вступив у Львівський державний інститут прикладного та декоративного мистецтва (далі - ЛДІПДМ, Інститут), де був студентом першого курсу відомого скульптора Івана Севери, який неодноразово зазнавав утисків від компартійної влади. Вказаний рік доцільно назвати початком «львівського періоду» у творчості В. Борисенка, який тривав майже 30 років.

На творче становлення В. Борисенка впливали викладачі Інституту, відомі митці, представники різних художніх шкіл: Петербурзької, Празької та Римської - Іван Севера, Будапештської - Йосип Бокшай, Варшавської - Вітольд Манастирський, Краківської - Роман Сельський (Моздир, 1987: 5).

У 1953 р. відбувся перший випуск створеного в 1946 р. ЛДІПДМу. Це був випуск В. Борисенка, дипломною роботою якого став проект пам'ятника, Героєві СРСР танкістові Олександрові Марченку, котрий 27 липня 1944 року підняв червоний прапор над львівською ратушою (Бадяк, 2007: 181). Захищена на «відмінно» гіпсова робота у 1955 р. виставлялася на Львівській обласній художній виставці, а в 1956 р. - на Львівській обласній виставці, присвяченій 700-річчю Львова (Архів ЛНАМ, Особова справа № 3185: 22). У списках творчих робіт, збережених в особовій справі скульптора, зазначено, що проект пам'ятника був переданий до Львівського історичного музею, проте і в Книзі вступу музейних предметів, i в Інвентарній книзі фондової групи «Скульптура» відсутня будьяка інформація про цю пам'ятку. 
Після закінчення навчання молодого скульптора скерували на Львівську кераміко-скульптурну фабрику Художнього фонду України (Горинь, 1996: 219). Тут, працюючи техноруком (Архів ЛНАМ, Особова справа № 3185: 19), він створив композиції «Лижник», «Хокеїст».

7 грудня 1959 р. В. Борисенко повернувся у рідну alma mater уже як старший викладач кафедри рисунку з окладом 600 крб. на місяць (на половину окладу) (Архів ЛНАМ, Особова справа № 3185: 1). Для порівняння, ставка доцента Інституту дорівнювала 2700 крб., а завідувача кафедри - 3250 крб. (ДАЛО, ф. Р-1653, оп. 1, спр. 328: 4). Це стало початком його викладацької, а згодом адміністративної кар'єри. У травні 1965 р. В. Борисенко обійняв посаду доцента кафедри рисунку (Архів ЛНАМ, Особова справа № 3185: 7), а в жовтні 1967 р. йому присвоєно вчене звання доцента (Архів ЛНАМ, Особова справа № 3185: 6). Після добровільної відставки ректора Інституту Якима Запаска, наказом міністра вищої і середньої освіти УРСР від 23 листопада 1971 р., В. Борисенка призначено ректором ЛДІПДМ (Архів ЛНАМ, Особова справа № 3185: 37). В січні 1973 р. скульптор обійняв посаду завідувача кафедри скульптури Інституту (Архів ЛНАМ, Особова справа № 3185: 68). 22 жовтня 1976 р. В. Борисенкові присуджено вчене звання професора кафедри скульптури (Архів ЛНАМ, Особова справа № 3185: 161).

Про перебування В. Борисенка на посаді ректора згадував львівський скульптор Дмитро Крвавич. На його думку, зміна Я. Запаска В. Борисенком «не мала жодного значення, бо у кінці 1960-х рр. Інститутом керували не ректори, а т. зв. «перші відділення» КГБ в Інституті. В Інституті було організовано мережу стукачів, КҐБ втручався у процес набору студентів, прийому на роботу викладачів, навіть виставляння оцінок студентам» (Крвавич, 1992: 15). Водночас за керівництва В. Борисенка ЛДІПДМ розпочав підготовку фахівців 3 моделювання одягу, проектування меблів, інтер'єру, художнього скла. У новому лабораторному корпусі запустили гутну піч (Бадяк \& Проць, 2006: 7). 
Паралельно скульптор не залишав творчості і громадської роботи. У середині 1960-х років В.Борисенко завідував секцією скульптури Львівського відділення Спілки художників УРСР (Горинь, 1996: 219). Від 1962 року скульптор був членом правління Союзу художників України, з червня 1964 року членом КПРС (Архів ЛНАМ, Особова справа № 3185: 19, 186). 31966 р. неодноразово обирався депутатом Львівської міської ради трудящих депутатів, від 1967 р. - член бюро Ленінського райкому КПУ (Архів ЛНАМ, Особова справа № 3185: 19). У 1964 році Президія Верховної Ради УРСР присвоїла В. Борисенкові звання заслуженого діяча мистецтв УРСР, а 23 липня 1976 р. - народного художника УРСР (Архів ЛНАМ, Особова справа № 3185: 49, 173).

У Львові скульптор мешкав у трикімнатній квартирі

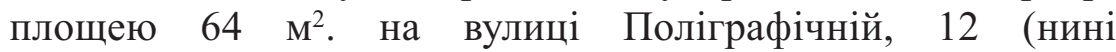
Ю. Романчука). У січні 1976 р. сім’я В. Борисенка переїхала в чотирикімнатне помешкання площею $85 \mathrm{~m}^{2}$ на вулиці Крупської, 13 (сьогодні - І. Рутковича) (Архів ЛНАМ, Особова справа № 3185: 140). Творча майстерня скульптора знаходилася на вул. Зеленій, 46.

Коли Шостий з’їзд художників УРСР обрав В. Борисенка секретарем Спілки художників України (Архів ЛНАМ, Особова справа № 3185: 19, 178), він з сім’єю переїхав до Києва. 29 червня 1977 р. В. Борисенко був звільнений з посади ректора Інституту у зв'язку з переходом на іншу роботу (Архів ЛНАМ, Особова справа № 3185: 189). У столиці В. Борисенко викладав у Київському художньому інституті, а у 1985-1988 роках обіймав посаду ректора цього ж вишу. Помер скульптор 8 січня 1990 р. у Києві.

На думку О. Голубця, творчість В. Борисенка йшла в руслі із популярною у тодішній львівській скульптурі тенденцією до узагальнення образів, значної «стилізації» основних об’ємів, їх «агресивного розташування в просторі», коли мова йшла про монументальні пам'ятки. Творчість В. Борисенка і його колег (Д. Крвавич, Е. Мисько, 
В. Одрехівський, В. Подольський) полягала в виконанні однотипних замовлень і відповідала пріоритетам радянської влади (Голубець, 2001: 106).

Ранні станкові роботи В. Борисенка знаходяться фондах та експозиції Львівського історичного музею: скульптурний портрет Нафталі Ботвіна (1956-1957), погруддя короля Данила Галицького (1961) та Володимира Леніна (1973). Мармуровий портрет Нафталі Ісаака Ботвіна, учасника комуністичного підпільного руху в міжвоєнному Львові, розстріляного за вироком польською військово-польового суду в тюрмі «Бригідки» 6 серпня 1925 р. (Терський, 2007: 272). був втіленням символу боротьби 3 «світовою буржуазією». Вважається, що митець створив символічний «мужній, психологічно змістовний образ», продемонструвавши вміння працювати з каменем і виявляти його природню красу (Яненко, 2006: 43). Одразу ж після створення пам'ятка експонувалася на київських виставках приурочених до 40-річчя Жовтня та 40річчя Радянської України (Архів ЛНАМ, Особова справа № 3185: 22). Скульптура виставлялася на постійній експозиції Відділу капіталістичного суспільства (Дунець \& Косів \& Мельник, 1987: 48). В експозиції Відділу існував куток, присвячений Н. Ботвіну, де окрім скульптури роботи В. Борисенка були представлені документи про арешт i розстріл підпільника, його фотографія, листівка ЦК КПЗУ, видана на його честь (Багрій \& Мельник \& Свєшнікова, 1976: 142). Після демократичних перетворень в Україні та зміни тематико-експозиційних концепцій, скульптурний портрет Н. Ботвіна був переданий на зберігання у фондову групу «Скульптура».

У 1960-х роках В. Борисенко зацікавився історичними постатями, розпочав працювати з деревом, створив скульптуру. «Данило Галицький». Передісторія цього твору є, напевне, типовою для усіх радянських митців. 19 квітня 1961 р., напередодні XXII з'їзу КПРС, на засіданні кафедри рисунку ЛДІПДМу обговорювалося питання підготовки до відкритого 
зібрання партії. Дирекція і парторганізації Інституту поставили перед викладачами завдання взяти на себе додаткові зобов'язання по творчій, методичній, науково-дослідній i навчальній роботі (ДАЛО, ф. Р-1653, оп. 1, спр. 363: 223). В. Борисенко, серед інших, зобов'язався «виконати портрет Данила Галицького, призначений для всесоюзної виставки» (ДАЛО, ф. Р-1653, оп. 1, спр. 363: 224). У звіті кафедри рисунку за 1961-1962 роки читаємо, що викладачі виконали індивідуальні плани наукових робіт, а їхні твори були представлені в обласних, республіканських і всесоюзних виставках, присвячених XXII з’їзду КПРС (ДАЛО, ф. Р-1653, оп. 1, спр. 401: 203). Скульптуру В. Борисенка оцінили добре, вона експонувалася на Республіканській виставці в Києві 1961 р. (Архів ЛНАМ, Особова справа № 3185: 25).

Крім станкової скульптури В. Борисенко брав участь у створенні монументальних пам'ятників у Львові i на Львівщині. В 1964 році у Львові відкрито пам'ятник Іванові Франку, авторства скульпторів Дмитра Крвавича, Еммануїла Миська, Якова Чайки, Валентина Борисенка, Василя Одрехівського та архітектора Андрія Шуляра. Пам'ятник оцінювали по-різному, проте сьогодні він $є$ невід'ємною частиною міського середовища. Ідея побудови пам'ятника I. Франку виникла ще в 1944-1945 роках в міських партійних організаціях. 4 квітня 1945 р. була видана постанова Ради народних комісарів УРСР і ЦК КП(б)У «Про збудування у місті Львові пам’ятників Тарасу Григоровичу Шевченку та Івану Яковичу Франку» (Пам’ятник І. Я. Франкові, 2021). Пам’ ятник мав стояти в Парку ім. I. Франка перед Львівським університетом. Тоді роботу доручили I. Севері, який розробив ескізи і каркас (Горинь, 1996: 201-202; Петренко, 2011). Проте проект так і не реалізували через високу вартість (586 000 крб.), а саму ідею втілили майже через двадцять років.

У співавторстві з скульптором Валентином Подольським та архітектором Анатолієм Консуловим В. Борисенко виконав пам’ятник друкареві Іванові Федорову, відкритий у 1977 році. 
Фігура друкаря, що стоїть на прямокутнику з темної бруківки, була досить нетрадиційним для того часу художнім вирішенням. Серед новаторських, як на свій час, скульптурних композицій вирізняли двадцятисемиметровий пам'ятник бійцям Першої Кінної армії, встановлений 1975 року у смт. Олесько Буського р-ну Львівської обл (демонтований у 2017 р. в процесі декомунізаціï). За цей твір В. Борисенко та Анатолієм Консулов отримали у 1978 році Шевченківську премію. На думку О. Голубця, пам’ятник був «вдалим прикладом композиційного задуму і способу входження в просторове середовище» (Голубець, 2001: 107).

У Києві В. Борисенко створив портрети Мікеланджело, Tараса Шевченка, Іллі Рєпіна для Актової зали Будинку художника в Києві (1978), портрет Данте Аліг’єрі (1980), меморіальні таблиці на честь давньоруського зодчого Петра Милонега і кінорежисера Леоніда Бикова (1982), а також монументальні горельєфи на фасаді теперішнього Українського дому (співавтор М. Білик, 1982). Уже будучи хворим, працював над моделлю фігури княгині Ольги для відновлення пам'ятника княгині Ользі, святому апостолу Андрію Первозванному та просвітителям Кирилу i Мефодію на площі перед Михайлівським Золотоверхим собором. Роботу В. Борисенко не зміг завершити, у 1996 р. пам'ятник відновили скульптори Віталій Сівко, Микола Білик та Віталій Шишов (Яценко, 1996).

Висновки. Соціалістичний реалізм як стиль і метод в мистецтві залишався домінуючим творчим напрямом протягом усієї доби СРСР. Особливий статус він отримав в скульптурному жанрі, покликаному підтримувати ідеологічні догми марксизму-ленінізму. Митці-скульптори змушені були працювати в умовах викривленого, обмеженого, деформованого, заідеологізованого суспільно-політичного середовища. Після остаточного приєднання Львова до СРСР/УРСР у 1944 р. радянські й партійні структури посилили політичний контроль над мистецькими об'єднаннями, навчальними закладами, окремими скульпторами. 
Аналіз життєвого шляху та творчості львівських митців Любомира Терлецького та Валентина Борисенка показав можливість існування відмінних практик в умовах авторитарного режиму. Любомир Терлецький, будучи репресованим за активну патріотичну позицію, зумів повернутись до власного покликання - творчості. Своєю художньою та науковою діяльністю Л. Терлецький глибше пізнавав і популяризував справжню тисячолітню історію України. Будучи людиною трагічної долі, але незломного характеру, Л. Терлецький обрав такий напрям творчості, який виражав неминучість державно-політичного і культурного відродження українського народу. Валентин Борисенко, як типовий талановитий представник радянської скульптурної школи, своєю творчістю добре вписувався в накинуту партією «згори» догму соціалістичного мистецтва. Адміністративна й партійна кар'єра В. Борисенка накладала відбитки і на творчу діяльність - митець неодноразово виконував відверті пропагандистські замовлення радянських партійно-політичних органів. Разом 3 тим, професійне зростання у львівській художній традиції, де наставниками В.Борисенка були вихованці краківської, празької, римської творчих шкіл, дозволило майстрові залишатися в системі українських культурно-ціннісних координат (звернення до княжої доби чи опришківського руху XVIII ст.) й частково відмежуватися від радянських ідеологічних нашарувань.

\section{ДЖЕРЕЛА ТА ЛІТЕРАТУРА}

1. Архів автора. Аудіозапис інтерв'ю з Богданом Горинем, 13 жовтня 2014 р.

2. Архів ЛІМу. - Архів Львівського історичного музею. Акти надходження музейних предметів. 1980; Інвентарна книга експонатів фондової групи «Скульптура», т. 1.

3. Архів ЛНАМ - Архів Львівської національної академії мистецтв. Особова справа № 3185 «Валентин Назарович Борисенко» (3 грудня 1959 р. - 29 червня 1977 р.). 
4. Багрій Р. С., Мельник Б. В., Свєшнікова І. О. Львівський історичний музей: путівник. Львів: Каменяр, 1976. 248 с.

5. Бадяк В. П. Фундатори. Львівська національна академія мистецтв. 1946-1953. Львів: ЛНАМ, 2007. 188 с.

6. Бадяк В., Проць І. Свято пам'яті й шани. Академічний журнал. 2006. № 1. С. 5-8.

7. Валентин Борисенко: альбом / упорядн. М. I. Моздир. Київ: Мистецтво, 1971. 14 с.

8. Валентин Борисенко: альбом / упорядн. М. I. Моздир. Київ: Мистецтво, 1987. 120 с.

9. ГДА СБУ у Львівській обл. - Галузевий державний архів СБУ у Львівській області. Справа № П 8145: Криминальное дело № 1265/39860. Т. 1.

10. Глинчак В. То яка ж Україна за князем тужила? День. 2012. № 13. C. 18.

11. Голубець О. Між свободою і тоталітаризмом: Мистецьке середовище Львова другої половини XX століття. Львів: Академічний експрес, 2001. 175 с.

12. Горинь Б. У пошуках берега: життя і творчість скульптора Івана Севери. Львів: Інститут українознавства ім. І. Крип’якевича НАН України, 1995. 239 с.

13. Грабовецький В. Скульптурна Довбушіана Валентина Борисенка. Івано-Франківськ, 2009. 116 с.

14. ДАЛО - Державний архів Львівської області. Ф. Р-1653. Львовский государственный институт прикладного и декоративного искусства Министерства высшего и среднего специального образования УССР. г. Львов.

15. Дунець В. О., Косів М. В., Мельник Б. В. Львівський історичний музей: путівник. Львів: Каменяр, 1987. 92 с.

16. 3 історії гімназії. URL: https://lag1.lviv.ua/page/pagehystory_ukr.

17. Коць-Григорчук Л. Слово про світильники у пітьмі (Україна в медальєрній пластиці Любомира Терлецького),, Збірник наукових пращь і матеріалів на пошану Лариси Іванівни Крушельницької / відп. ред М. М. Романюк. Львів, 1998. C. 333-338 
18. Крвавич Д. Львівський державний інститут прикладного та декоративного мистецтва за 45 років свого існування. Сходження. Матеріали ювілейної науково-творчої конферениій присвяченої 45-річчю заснування ЛДІПДМ. Львів, 1992. C. 7-21.

19. Литвин М., Ільницький В. (). Західноукраїнська соціогуманітаристика в умовах сталінського тоталітаризму: просопографічний та комеморативний аспекти. Проблеми гуманітарних наук: збірник наукових працьь Дрогобицького державного педагогічного університету імені Івана Франка. Серія Історія. 2020. Вип. 4/46. С. 208-228. doi: https://doi.org/10.24919/2312-2595.4/46.215316.

20. Літопис руський / переклад Л. С. Махновець. Київ: Дніпро, 1989. 590 с.

21. Мельник I. Львівська академічна гімназія. URL: http://postup.brama.com/usual.php?what=44948.

22. Мусій М. М. Соцреалізм і художник: проблема вибору. Львівський досвід 1960 - 1980-х рр. Наукові записки. Національного університету "Києво-Могилянська академія». 2009. Том 88: Теорія та історія культури. С. 71-74).

23. Нестайко М. О. Львів мистецький (1965-1985 рр.): наука, культура, влада. Львів: ЛННБ України ім. В. Стефаника НАН України, 2017244 с.

24. Пам’ятник I. Я. Франкові. URL: https:/uma.lvivcenter.org/ $\mathrm{uk} / \mathrm{photos} / 4856$.

25. Петренко М. Ми пам'ятаємо. Школа невпокореного маестро Івана Севери. URL: http://zaxid.net/home/ showSingleNews.do?mi_pamyatayemo_shkola_nevpokorenogo_m aestro_ivana_severi\&objectId=1129572.

26. Сливка Ю. Патріотичний вчинок видатного митця i вченого. Л. Терлецьький. Етногенез украӥнського народу. Львів: Інтелект Бізнес. 2007. С. 3-20

27. Терлецький Л. Етногенез українського народу. Львів: Інтелект Бізнес. 2007. 631 с. 
28. Терський С. Ботвін Нафталі Ісаак. Енциклопедія Львова / ред. А. Козицький, І. Підкова. Львів: Літопис, 2007. Т. I (А-Г). C. 272.

29. Фіголь Р., Криса Л. Личаківський некрополь: путівник. Львів. 2006. 480 с.

30. Шах С. Львів - місто моєї молодости. Часть III. Цісарсько-Королівська Академічна Гімназія. Мюнхен, 1956. $362 \mathrm{c}$.

31. Яненко А. Ректор, навчитель, художник. Украӥнська культура. 2006. № 10 (961). С. 43.

32. Яценко О. Княгиня Ольга, святі Кирило і Мефодій знову прийшли у Київ і зупинилися там, де пробудуть вовіки віків: про відновлення і освячення відновл. пам'ятника архіт. Чac/Time. 1996. 31 травня.

33. Яців Р. Образотворче мистецтво. Історія Львова у трьох mомах / редкол. Я. Ісаєвич, М. Литвин, Ф. Стеблій. Львів: Центр Свропи, 2007. Том 3. С. 189-190.

\section{REFERENCES}

1. Arkhiv avtora. Audiozapys interv'iu z Bohdanom Horynem, 13 zhovtnia 2014 r. [Author's archive. Audio recording of an interview with Bohdan Horyn, October 13, 2014.] [in Ukrainian].

2. Arkhiv LIMu. - Arkhiv Lvivskoho istorychnoho muzeiu. Akty nadkhodzhennia muzeinykh predmetiv. 1980; Inventarna knyha eksponativ fondovoi hrupy «Skulptura», t. 1. [Archive of Lviv Historical Museum. Acts of receipt of museum objects. 1980; Inventory book of exhibits of the stock group «Sculpture», vol. 1.] [in Ukrainian].

3. Arkhiv LNAM - Arkhiv Lvivskoi natsionalnoi akademii mystetstv. Osobova sprava № 3185 «Valentyn Nazarovych Borysenko» (3 hrudnia 1959 r. - 29 chervnia 1977 r.) [Archive of the Lviv National Academy of Arts. Personal file № 3185 «Valentyn Nazarovych Borysenko» (December 3, 1959 - June 29, 1977)] [in Ukrainian]. 
4. Bahrii, R. S., \& Melnyk, B. V., \& Svieshnikova, I. O. (1976). Lvivskyi istorychnyi muzei: putivnyk [Lviv historical Museum: guidebook]. Lviv: Kameniar [in Ukrainian].

5. Badiak, V. P. (2007). Fundatory. Lvivska natsionalna akademiia mystetstv. 1946-1953 [Founders. Lviv National Academy of Arts. 1946-1953]. Lviv: LNAM [in Ukrainian].

6. Badiak, V., \&, Prots, I. (2006). Sviato pamiati y shany [A holiday of remembrance and honor]. Akademichnyi zhurnal, 1, 58 [in Ukrainian].

7. Mozdyr, M. I. (Comps.). (1971). Valentyn Borysenko: albom [Valentyn Borysenko: album]. Kyiv: Mystetstvo [in Ukrainian].

8. Mozdyr, M. I. (Comps.). (1987). Valentyn Borysenko: albom [Valentyn Borysenko: album]. Kyiv: Mystetstvo [in Ukrainian].

9. HDA SBU u Lvivskii obl. - Haluzevyi derzhavnyi arkhiv SBU u Lvivskii oblasti. Sprava № P 8145: Kriminalnoe delo № 1265/39860. T. 1. [Sectoral state archive of the Security Service of Ukraine in Lviv region. Folder № P 8145: Criminal proceedings № 1265/39860. T. 1.] [in Russian].

10. Hlynchak, V. (2012). To yaka zh Ukraina za kniazem tuzhyla? [So what kind of Ukraine longed for the prince?] Den, 13, 18 [in Ukrainian].

11. Holubets, O. (2001). Mizh svobodoiu i totalitaryzmom: Mystetske seredovyshche Lvova druhoi polovyny XX stolittia [Between freedom and totalitarianism: The artistic environment of Lviv in the second half of the XX century]. Lviv: Akademichnyi ekspres [in Ukrainian].

12. Horyn, B. (1996). U poshukakh bereha: zhyttia $i$ tvorchist skulptora Ivana Severy [In search of the shore: the life and work of sculptor Ivan Severa]. Lviv: Instytut ukrainoznavstva im. I. Krypiakevycha NAN Ukrainy [in Ukrainian].

13. Hrabovetskyi, V. (2009). Skulpturna Dovbushiana Valentyna Borysenka [Sculptural Dovbushiana of Valentyn Borysenko]. IvanoFrankivsk [in Ukrainian].

14. DALO - Derzhavnyi arkhiv Lvivskoi oblasti. F. P-1653. Lvovskiy gosudarstvennyy institut prikladnogo i dekorativnogo 
iskusstva Ministerstva vysshego i srednego spetsialnogo obrazovaniya USSR. g. Lvov [State Archives of Lviv Oblast. F. P1653. Lviv State Institute of Applied and Decorative Arts of the Ministry of Higher and Secondary Specialized Education of the Ukrainian SSR. Lviv] [in Russian].

15. Dunets, V. O., \& Kosiv, M. V., \& Melnyk, B. V. (1987). Lvivskyi istorychnyi muzei: putivnyk [Lviv historical Museum: guidebook]. Lviv: Kameniar [in Ukrainian].

16. $Z$ istorii himnazii [From the history of the school]. (2021). Retrieved from https://lag1.lviv.ua/page/page-hystory_ukr [in Ukrainian].

17. Kots-Hryhorchuk, L. (1998). Slovo pro svitylnyky u pitmi (Ukraina v medaliernii plastytsi Liubomyra Terletskoho) [A word about lamps in the dark (Ukraine in Liubomyr Terletskyi's medal sculpture)]. In M. M. Romaniuk (Ed.), Zbirnyk naukovykh prats $i$ materialiv na poshanu Larysy Ivanivny Krushelnytskoi (pp. 333338). Lviv [in Ukrainian].

18. Krvavych, D. (1992). Lvivskyi derzhavnyi instytut prykladnoho ta dekoratyvnoho mystetstva za 45 rokiv svoho isnuvannia [Lviv State Institute of Applied and Decorative Arts for 45 years of its existence.]. Skhodzhennia. Materialy yuvileinoi naukovo-tvorchoi konferentsii prysviachenoi 45-richchiu zasnuvannia LDIPDM. (pp. 7-21). Lviv [in Ukrainian].

19. Lytvyn, M., \& Ilnytskyi, V. (2020). Zakhidnoukrainska sotsiohumanitarystyka $\mathrm{v}$ umovakh stalinskoho totalitaryzmu: prosopohrafichnyi ta komemoratyvnyi aspekty [Western Ukrainian sociohumanitarian studies in the conditions of Stalin's totalitarism: prosopographical and commemorative aspects]. Problemy humanitarnykh nauk: zbirnyk naukovykh prats Drohobytskoho derzhavnoho pedahohichnoho universytetu imeni Ivana Franka. Seriia Istoriia, 4/46, 208-228. doi: https://doi.org/10.24919/23122595.4/46.215316 [in Ukrainian].

20. Makhnovets, L. Ye. (Trans1.). (1989). Litopys ruskyi [Rus' Chronicle]. Kyiv [in Ukrainian]. 
21. Melnyk, I. (2005). Lvivska akademichna himnaziia [Lviv Academic Gymnasium]. Retrieved from http://postup.brama.com/ usual.php?what=44948 [in Ukrainian].

22. Musii, M. M. (2009). Sotsrealizm i khudozhnyk: problema vyboru. Lvivskyi dosvid 1960 - 1980-kh rr. [Socialist realism and the artist: the problem of choice. Lviv experience of 1960 - 1980s]. Naukovi zapysky. Natsionalnoho universytetu «Kyievo-Mohylianska akademiia». Tom 88: Teoriia ta istoriia kultury (pp. 71-74). Kyiv [in Ukrainian].

23. Nestaiko, M. O. (2017). Lviv mystetskyi (1965-1985 rr.): nauka, kultura, vlada [Artistic Lviv (1965-1985): science, culture, power]. Lviv: LNNB Ukrainy im. V. Stefanyka NAN Ukrainy [in Ukrainian].

24. Pamiatnyk I. Ya. Frankovi [Monument to I. Ya. Franko] (2021). Retrieved from https://uma.lvivcenter.org/uk/photos/4856 [in Ukrainian].

25. Petrenko, M. (2011). My pamiataiemo. Shkola nevpokorenoho maestro Ivana Severy [We remember. School of the unconquered maestro Ivan Severa]. Retrieved from http://zaxid.net/home/showSingleNews.do?mi_pamyatayemo_shko la_nevpokorenogo_maestro_ivana_severi\&objectId=1129572 [in Ukrainian].

26. Slyvka, Yu. (2007). Patriotychnyi vchynok vydatnoho myttsia i vchenoho [A patriotic act of an outstanding artist and scientist]. L. Terletskyi. Etnohenez ukrainskoho narodu [Ethnogenesis of the Ukrainian people] (pp. 3-20). Lviv: Intelekt Biznes [in Ukrainian]. 27. Terletskyi, L. (2007). Etnohenez ukrainskoho narodu [Ethnogenesis of the Ukrainians]. Lviv: Intelekt Biznes [in Ukrainian].

28. Terskyi, S. (2007). Botvin Naftali Isaak [Botvin Naftali Isaak]. A. Kozytskyi \& I. Pidkova (Ed.), Entsyklopediia Lvova. Vol. I (A-G) (p. 272). Lviv: Litopys [in Ukrainian].

29. Fihol, R., Krysa, L. (2006). Lychakivskyi nekropol: putivnyk [Lychakiv necropolis: a guide]. Lviv [in Ukrainian]. 
30. Shakh, S. (1956). Lviv - misto moiei molodosty. Chast III. Tsisarsko-Korolivska Akademichna Himnaziia [Lviv - the city of my youth. Part III. Imperial-Royal Academic Gymnasium]. Miunkhen [in Ukrainian].

31. Yanenko, A. (2006). Rektor, navchytel, khudozhnyk [Rector, teacher, artist]. Ukrainska kultura, 10 (961), 43.

32. Yatsenko, O. (1996). Kniahynia Olha, sviati Kyrylo i Mefodii znovu pryishly u Kyiv i zupynylysia tam, de probudut voviky vikiv: pro vidnovlennia i osviachennia vidnovl. pamiatnyka arkhit [Princess Olga, Saints Cyril and Methodius came to Kyiv again and stopped where the ages of ages will remain: about the restoration and consecration of the restored architectural monument]. Chas/Time, 31 travnia [in Ukrainian].

33. Yatsiv, R. (2007). Obrazotvorche mystetstvo [Visual arts]. Ya. Isaievych, M. Lytvyn, F. Steblii (Eds.). Istoriia Lvova u trokh tomakh. Tom 3 [History of Lviv in three volumes. Volume 3] (pp. 189-190). Lviv: Tsentr Yevropy [in Ukrainian].

\section{АНОТАЦІЯ}

Мета роботи полягає у комплексному дослідженні суспільно-політичних та творчих стратегій львівських митиів-скульпторів - майстра української медальєрної пластики Любомира Терлецького та твория монументальної i станкової скульптури Валентина Борисенка - у другій половині XX століття. Методологічну основу роботи склали напрацювання в галузях політичної історії, культурної антропології, соціальної історії, мистецтвознавства. Пропоноване дослідження грунтується на методологічному приниипі «case study», який дозволив застосувати системноструктурний метод до розкриття багатовимірної історії повсякдення - творчого та кар'єрного шляхів львівських скульпторів радянського періоду. Наукова новизна праці полягає в успішному застосуванні мікроісторичного підходу для демонстрації тогочасних опозиційних моделей «творчість-диктатура» та «митець-авторитарна влада», а 
також способів їх вираження в умовах радянського політикоідеологічного контролю. Доведено, щуо львівські митці-скульптори Л. Терлецьький та В. Борисенко пройшли відмінний шлях професійного та творчого зростання, й відтак своєю діяльністю виражали різні політичні ци культурні горизонти. Висновки. Мистецьке середовище післявоєнного Львова формувалося через активне підпорядкування художньої творчості иілям радянського державно-партійного апарату. Впровадження стилю сочіалістичного реалізму вимагало від митиів пристосування до примітивних форм вираження ідеологічних постулатів СРСР/УРСР. Залишаючись домінантним напрямом мистецтва, соиіалістичний реалізм змушував львівських скульпторів вибудувати індивідуальні стратегї творчості, професійного зростання, взаємовідносин із владою. Любомир Терлецький (1922-1993), будучи замолоду репресованим за активну патріотичну позицію, пройшов випробування радянськими таборами та, після реабілітації, повернувся до творчого життя. Не маючи ілюзій щуодо перспектив авторитарного радянського режиму він пізнавав та популяризував тисячолітню історію України. Не лише скульптурною творчістю, але й науковою роботою митець демонстрував незломний характер та переконання про неминучість державно-політичного $i$ культурного відродження украӥнського народу. Автор монументальних та станкових скульптур Валентин Борисенко (1929-1990) увійшов в історію як типовий представник радянської скульптурної школи, майстер, щуо добре вписувався в накинуту партією «згори» догму сочіалістичного мистецтва. Водночас, будучи сформованим у львівській художній традиції (вчителями В. Борисенка були вихованці краківської, празької, римської творчих шкіл), він, через звернення до княжсої доби чи народних месницьких характерів XVIII cm., частково відмежовувався від радянських ідеологічних нашарувань. Обравии партійну й адміністративну кар'єру В. Борисенко неодноразово виконував пропагандистські роботи на замовлення партійно-політичних структур. 
Ключові слова: Львів, СРСР/УРСР, скульптура, сочіалістичний реалізм, Любомир Терлецький, Валентин Борисенко, партійно-ідеологічний контроль.

\section{АННОТАЦИЯ}

Цель работы заключается в комплексном исследовании общественно-политических и творческих стратегий львовских художников-скульпторов - мастера украинской медальерной пластики Любомира Терлецкого и создателя монументальной и станковой скульптуры Валентина Борисенко - во второй половине XX века. Методологическую основу работь составили наработки в области политической истории, культурной антропологии, сочиальной истории, искусствоведения. Предлагаемое исследование основывается на методологическом приничипе «саse study», который позволил применить системно-структурный метод к раскрытию многомерной истории повседневности - творческого и карьерного путей львовских скульпторов советского периода. Научная новизна работь заключается в успешном применении микроисторичного подхода для демонстрации тогдашних оппозиционных моделей «творчество-диктатура» $u$ «художник-авторитарная власть», а также способов их выражения в условиях советского политико-идеологического контроля. Доказано, что львовские художники-скульпторы Л. Терлецкий и В. Борисенко прошли отличный путь профессионального и творческого роста, и поэтому своей деятельностью выражали различные политические и культурные горизонтыл. Bыводы. Художественная среда послевоенного Львова формировалось за активное подчинение художественного творчества иелям советского государственно-партийного аппарата. Внедрение стиля сочиалистического реализма требовало от художников приспособления $к$ примитивным формам выражения идеологических постулатов СССР / УССР. Оставаясь доминантным направлением искусства, сочиалистический 
реализм заставлял львовских скульпторов выстроить индивидуальные стратегии творчества, профессионального роста, взаимоотночений с властью. Любомир Терлецзкий (1922-1993), будучи в молодости репрессированным за активную патриотическую позицию, прошел испьтания советскими лагерями и, после реабилитацчии вернулся к творческой жизни. Не имея иллюзий относительно перспектив авторитарного советского режсим, он познавал u популяризировал тысячелетнюю историю Украинь. Не только скульптурной творчеством, но и научной работой художник демонстрировал несгибаемый характер и убежсдения о неизбежнности государственно-политического и культурного возрожсения украинского народа. Автор монументальных и станковых скульптур Валентин Борисенко (1929 - 1990) вошел в историю как типичный представитель советской скульптурной школь, мастер, который хорошо вписывался в накинутую партией «сверху» догму сочуиалистического искусства. В то же время, будучи сформированным в львовской художественной традиции (учителями В.Борисенко бьли воспитанники краковской, пражской, римской творческих икол), он, через обрашуение к княжеству или народньлм мстительским характерам XVIII в., частично отстранялся от советских идеологических наслоений. Выбрав партийную и административную карьеру, В. Борисенко неоднократно выполнял пропагандистские работьл на заказ партийно-политических структур.

Ключевые слова: Львов, СССР / УССР, скульптура, социиалистический реализм, Любомир Терлецкий, Валентин Борисенко, партийно-идеологический контроль. 